\title{
Suggestions on the Construction of Financial Informatization in Chinese Universities
}

\author{
Haiping Guo \\ Finance Department \\ Wuhan Polytechnic University \\ Wuhan 430023, China \\ 24212569@qq.com
}

\author{
Jun Li \\ Finance Department \\ Wuhan Polytechnic University \\ Wuhan 430023, China \\ 346678628@qq.com
}

\begin{abstract}
The emergence of new technologies such as big data, cloud computing and intelligent networking has promoted the transformation of the existing financial management model. In order to provide a reference to further improve the level of financial management information construction in Chinese universities, this paper makes a detailed analysis of the current situation of financial informatization construction, and puts forward some concrete suggestions aiming at the main problems such as backward concept, isolated information island, weak security awareness, weak internal control mechanism and shortage of professional talents. It is pointed out that the construction of financial informationization in Chinese universities is urgent. On the premise of ensuring the security of information data, we must speed up the overall development of financial informationization in Chinese universities.
\end{abstract}

Keywords-Chinese universities; Financial Informatization; Countermeasures and Suggestions

\section{INTRODUCTION}

With the continuous emergence of new technologies-big data, cloud computing and intelligent networking, financial management mode has also changed, and financial work has become simpler and more efficient. The Outline of the National Plan for Long-term Reform and Development in Education (2010-2020) points out that information technology has a revolutionary impact on education development and must be attached great importance to. From the perspective of the long-term development of Chinese universities, the financial technology and management mode of Chinese universities must be upgraded from the aspect of informationization in order to adapt to the changing social trend and ensure the stability and orderliness of the financial management of Chinese universities [1]. Financial information management is an activity for management departments and business operators to collect, collate, analyze, predict and supervise financial information of enterprises by applying modern information technology and management means with the purpose of improving decision-making and management efficiency. Financial informationization in Chinese universities is to make good use of advanced information technologies to strengthen financial management, improve the efficiency of the use of funds, so that policy makers can make scientific decisions based on timely and reliable financial information. On January 1, 2019, the new "Government Accounting System" was formally implemented. To meet the requirements of "dual-function, dual-basis and double-report" accounting mode, universities need to improve the construction of financial information as soon as possible.

\section{MAJOR PROBLEMS IN THE CONSTRUCTION OF FINANCIAL INFORMATIZATION IN CHINESE UNIVERSITIES}

\section{A. The Backward Concept of Financial Informatization}

Recently, China's Chinese universities have developed rapidly, and the economic business is becoming more and more complex. With the reform of higher education and the deepening of educational informatization, the construction of financial informatization in domestic Chinese universities has made considerable progress. Most universities' financial informatization has entered the LAN stage from the stage of computerized accounting. However, the concept of "attaching importance to budget, neglecting final accounts, and neglecting performance" has not changed in many Chinese universities. The content of financial analysis mostly stays in the aspects of revenue and expenditure of funds, financial situation analysis, etc. However, there is no performance evaluation on the use efficiency of funds, ignoring the important role of financial informatization in financial management. At present, many university financial information systems have been transformed to network and intelligence. The traditional single-computer computerized system or financial LAN system can't meet the needs of university financial management. Hardware and software systems need to be upgraded. China's domestic universities have basically realized the computerization of accounting, and are in the transition from digital campus financial platform with resources to intelligent campus financial comprehensive information service platform with massive data support and personalized services for teachers and students [2]. Under the background of "Internet+", the key of financial informationization of Chinese universities is the management of data level, making good use of big data technology to provide scientific and reasonable data support for the decision-making of the school leadership. With the further development of big data technology and artificial intelligence, machines can not only accomplish some tedious and repetitive work, but also replace human beings to make some decisions and management. It can be said that they potentially threaten the existing financial positions of the personnel[3]. The Economist estimates that accounting and 
auditing are $94 \%$ more likely to be replaced by robots in the next 20 years, only second to telemarketers.

\section{B. Information Isolation Problem}

In Chinese universities, the development of information construction is rapid. A large number of information systems have been built in various departments of the university, such as financial management system, student management system, asset management system, scientific research management system, personnel management system, etc. However, in many Chinese universities, different subsystems of information platform are developed independently with their own independent databases, and the caliber of information statistics is not the same. Due to the lack of uniform interface, data transmission between departments is almost entirely dependent on copies, and the data is often inconsistent, resulting in the inadequate interaction and sharing of system data between subsystems, and information islands occur at last. Often, in order to submit some information, a lot of repeated work is needed, which affects the efficiency of collecting financial information. For example, many universities' financial budget system and financial accounting system are separated from each other. If we need to inquire about the overall implementation of special financial funds, we need to process the data twice. The scientific research system and the financial system are not related. The information needed by each department needs to be logged into two systems and operated separately. The information is not shared. Some Chinese universities have constructed information technology, but it is difficult to give full play to the role of modern information technology because of insufficient comprehensive consideration and lack of overall planning. The formation of financial information flow in Chinese universities does not break the division of organization and labor, and does not realize the coordination of various process links and the integrated management of business flow. It can't automatically form a rich, complete and accurate financial information flow [4].Budget and final accounts data analysis are separated from each other, and budget implementation progress can't be monitored in real-time, since financial data is stored sporadically, the utilization rate of financial data is low, and data analysis and mining is not in place [5].

\section{Weak Awareness of Network Information Security}

Although the construction of financial informationization in Chinese universities has greatly improved the work efficiency of accountants and brought about the sharing of financial data, the accounting processing system relies too much on the network system and has uncertain risks. In an era of big data, financial data are transmitted through computer network in information collection, processing, input and output, and there is the possibility of being stolen, leaked and tampered with by hackers or illegal elements. With the rapid development of information technology, computer viruses such as Trojan horse virus and extortion virus are widely spread, and security vulnerabilities can't be completely avoided. At present, many university information systems are not equipped with professional technical personnel, only relying on the school network management center or third-party enterprise management; however, the university network information security response ability is poor. Therefore, while guarding against financial risks, it is also an important task for university financial management to take effective measures to plug network security loopholes.

\section{Weak Internal Control Mechanism}

With the advancement and popularization of information technology, the informatization of internal control has become an important means to strengthen internal control management and improve management efficiency. Since 2016, the construction of internal control in Chinese universities in China has been advancing in full swing, but the informationization of the construction of internal control in Chinese universities is still relatively backward. The informationization construction of universities in our country develops relatively late, and the informationization construction of internal control has just started. There is still a long way to go in the informationization of budget management, revenue and expenditure business management, asset management, government procurement, contract management and other business levels. Traditionally, internal control management is accounting control, and internal audit is simply post-review. Without the informationization of internal control, the system of post separation is difficult to achieve effectively, and hidden box operation and favoritism fraud occur from time to time. Some Chinese universities do not have enough management control over some key links, and the internal control system is not perfect. They neglect the risk identification and risk assessment of the overall business activities. At the same time, there are some phenomena such as incomplete information disclosure in varying degrees. The effectiveness of internal control in Chinese universities is closely related to the degree of information disclosure. One of the main reasons for corruption in Chinese universities is the inadequate performance of the information force's responsibility for reporting and supervising [6].

\section{E. Shortage of Inter-disciplinary Talent}

Financial informationization in Chinese universities combines informationization technology with financial management knowledge effectively. Chinese universities need talents who are skilled in the application of modern information technology and have a solid knowledge of financial management, so as to be conducive to the construction and development of financial informationization in Chinese universities. However, due to historical and professional reasons, much financial personnel in Chinese universities are a bit old at their ages with a single knowledge structure. Although they are familiar with the traditional financial business of universities, they lack computer and information technology skills. It is difficult for them to deal with big data problems and they are even reluctant to accept the new network finance. The newly enrolled young financial personnel grasp the means of informatization, but they lack basic financial knowledge and practical experience. In a word, the lack of professional talents with both financial skills and informatization skills, coupled with the lack of systematic personnel training plan, makes the construction of financial informatization in Chinese universities meet the bottleneck of development. 


\section{COUNTERMEASURES AND SUGGESTIONS ON PERFECTING THE CONSTRUCTION OF FINANCIAL INFORMATIZATION IN CHINESE UNIVERSITIES}

\section{A. Changing the Management Concept and Strengthen the Recognition of the Importance of Financial Information Construction}

Since Chinese universities develop continuously, more and more financial data are generated in Chinese universities. The collection, processing and analysis of massive data bring great challenges to financial personnel. In addition, mobile payments such as Alipay and WeChat are becoming more and more popular. The good user experience brought by mobile payment brings new demands for campus consumption and payment. Financial management informationization is essentially a kind of innovation of school human resources, financial and material management concept by using computer technology. Under the background of the integration of internet and accounting, the whole accounting industry is facing unprecedented changes. In May 2017, the financial robots represented by Deloitte's "Xiaoqin Man" came out. For the first time, AI technology was introduced into accounting, taxation, auditing and other work. It replaces the financial personnel to complete the data entry, presidential accounting, auditing and accounting work which are originally needed to be handled by a large number of manpower, which triggers the excitement and intense discussion of the financiers on whether AI would replace part of the financial work. [7].In future enterprises, the existing financial posts will disappear, such as cashier, general ledger accounting, fixed assets accounting, cost accounting and tax accounting, while new posts such as data asset posts, information demand posts, algorithm design and maintenance posts, human-computer interaction posts will emerge [3]. These changes promote the management of Chinese universities to keep pace with the times. Chinese universities must change the traditional management mode, actively applying information technology to the financial management of Chinese universities to establish and improve the financial information system. Chinese universities should conform to the requirements of the times, actively building leading groups for information construction to gather ideas and draw up plans and strategies for the implementation of financial information. All departments in the university should also unite their ideas and work together to promote the orderly development of information construction. Chinese universities must increase investment in financial management reform, so as to vigorously enhance the construction of financial management information infrastructure in Chinese universities.

\section{B. Unifying Data and Information to Build a Comprehensive Financial Information Service Platform}

It is a general trend to build a comprehensive financial information service platform to unify data information and realize data sharing. The construction of comprehensive university financial information system can not only meet the needs of "data sharing" of various departments in the university, but also meet the needs of different information users, such as university administrators, students, parents, education authorities, and so on. At the same time, it can also take into account the needs of university personalized management and accounting automation. Building a comprehensive service platform can help Chinese universities gather the information of educational administration, personnel, science and technology, assets, logistics, student employment and other functional departments. Departments in Chinese universities can exchange and share these information resources, effectively integrating financial management functions such as calculation, analysis and decision-making in the platform to meet the needs of different user groups and enhance the utilization rate of data information. By building data exchange centers in universities, different campuses and different business systems can be connected, and a unified software interface can be constructed to realize data docking, break information islands and promote data information sharing. Through data sharing, the repetitive work of data acquisition, input and statistics can be reduced, and the business of tuition collection, wage distribution, funds allocation, budget preparation and implementation, performance evaluation can become faster and safer, and the work efficiency can be greatly improved. By means of intermediate database technology, it realizes docking with the three-party payment platform such as online banking system, Alipay or WeChat, and provides electronic payment and feedback platform for donation and cooperation of off-campus users[8]. The functions of a financial management information system must increase or strengthen the functions of financial supervision, information collection and data analysis. In addition to daily business processing, it should also serve the overall decision-making and scientific management of Chinese universities.

\section{Monitoring Network Risks and Strengthen Financial Information Security Construction}

The data of university financial information platform is in an open network environment, so it is very important to strengthen the system security construction. First of all, we should ensure the stability of the whole campus network, avoiding the loss of financial data caused by sudden network disconnection. Financial personnel should also raise the awareness of network security, regularly detecting and killing network viruses, and timely do a good job of data backup. Secondly, system administrators should set up the access rights of network interface, and strictly screen outsiders and information. At the same time, system operators should manage their own operation passwords, and adopt encryption settings for data transmission to prevent information leakage. Finally, the supervision and maintenance of the system must be strengthened. Security risks needs to be prevented to ensure the normal operation of the system. Now when users log on to the financial information platform, they usually use account number and password. It is suggested that mobile phone short message authentication be added. Financial departments should have exclusive computer rooms equipped with powerful servers to ensure the normal operation of the financial system.

\section{Promoting the Construction of Hardware and Software and Improve the Construction System of Internal Control}

Building a modern university internal control information system has become the key to university scientific management. Information-based financial management, accounting, control and supervision are the bases of internal control in Chinese 
universities. Information construction of internal control should cover more areas, especially in procurement management, contract management and bidding management. Chinese universities need to increase investment, integrate the school's economic and business information system, build a comprehensive financial information platform, and replace manual operation with computer control, which can leave traces of system operation, not only protecting the integrity and security of information, but also improving efficiency. In the construction of financial information system, the function of internal control of school economic activities is embedded in the platform, and the rules, methods and procedures of process control are placed in the system to realize effective whole-process monitoring and comprehensive evaluation of school economic activities, and strengthen financial internal control by tracking and evaluating indicators. For example, we should supervise the budget implementation of special funds in Chinese universities, giving early warnings and intervention when the implementation progress is obviously too slow or too fast. Chinese universities should be alert to information disclosure and take the initiative to accept the supervision of teachers, students, parents and other relevant stakeholders of society [9].

\section{E. Introducing Talents Internally and Externally to Build a High-quality Financial Information Management Team}

With the continuous development of artificial intelligence, the future accounting professionals will probably be divided into four categories: the first is system researchers; the second is system designers; the third is system operators; and the fourth is senior managerial accountants or senior managers who make final decisions using the information provided by the system [10].In an era of big data, it is very important to train comprehensive accounting professionals. College financial personnel should not only master financial and economic expertise, but also constantly learn new information technology, improve foreign language level and use innovative thinking to deal with problems encountered in their work. Firstly, we should invite experts from the industry to conduct systematic training in Chinese universities so as to improve the comprehensive quality of existing financial managers. Secondly, while strengthening the study of financial professional knowledge; financial personnel should actively learn information technology knowledge, computer operation skills and new technologies such as network and database. Financial personnel should also be good at making use of financial software for financial information processing and analysis to further improve the efficiency and quality of financial work. Finally, Chinese universities should actively recruit excellent financial personnel with a variety of financial and computer skills. It is suggested that some financial and computer talents must be responsible for the inspection and supervision of the daily financial information system. Thus, the efficiency of internal control and high level of financial management can be guaranteed.

\section{CONCLUSION}

With the rapid development of information technology and the practical requirements for the construction of digital campus and internal control informatization in Chinese universities, the building of financial informatization data sharing platform in Chinese universities has become an inevitable trend. Universities should update their management concepts based on their own actual situation; build a high-quality financial informatization management team to ensure the security of information and data, to improve the level of financial management, and to make contributions to the healthy development of Chinese universities.

\section{REFERENCES}

[1] Wu Tao. Research on University Financial Informatization Construction Based on Digital Campus Background [J]. Science and Technology Communication, 2018 (7): 130-131 (In Chinese)

[2] Fan Qunpeng, Zhu Jiaxuan. On the Construction of Financial Informatization in Chinese universities [J]. Commercial Economy, 2018 (9): 184-186(In Chinese)

[3] Li Wenyi, Li Li Li, Cao Jing, Chen Xinqiao. On the Concept and Future Application Scene of Intelligent Finance [J]. Monthly Journal of Finance and Accounting, 2018 (05) 40-43(In Chinese)

[4] Zhao Deping. University Financial Information System Architecture Based on Business Process [J]. Journal of Sichuan Normal University (Natural Science Edition) 2016 (3): 304-308(In Chinese)

[5] Pengwei. Construction of University Financial Cockpit Platform [J]. Monthly Journal of Finance and Accounting, 2018 (17): 109-113(In Chinese)

[6] Lang Fushan. Construction of internal control in Universities from the perspective of network governance [J]. Monthly Journal of Finance and Accounting 2017 (16): 23-26(In Chinese)

[7] Cheng Ping, Wang Jianjun. Based on CDIO's "Internet + accounting" financial intelligence application ability training -- take Chongqing University of Technology MPACC education as an example, [J]. finance journal Monthly, 2018 (12) 23-31(In Chinese)

[8] Wang Di. Top level design of financial information in Chinese universities in the era of "Internet + " [J]. economic research reference, 2017 (46): 75-77(In Chinese)

[9] Guo Haiping. Problems and Countermeasures in the construction of internal control in Chinese universities [J]. Journal of Wuhan University of Light Industry, 2018 (4): 95-99(In Chinese)

[10] Business Debate, Chen Jianyun, Daihua Jiang, Luoyang. Discussion on the Status of Financial Accounting Course for Accounting Major in Applied Universities in the Accounting Robot Era [J]. Monthly Journal of Finance and Accounting, 2018 (05): 132-136(In Chinese) 